\title{
Indigenous Knowledge and Disaster Risk Reduction
}

\author{
John Carver Scott ${ }^{1}$
}

Recebido em 16/05/2020 - Aceito em 19/08/2020

1 Center for Public Service Communications. United States of America. <jcscott@cpsc.com>.

\begin{abstract}
This article attempts to shed light on challenges to native peoples use of indigenous knowledge to reduce risk and mitigate effects of natural hazards, including wildland fire, and calls attention to ways in which traditional practice, together with contemporary experience, may help indigenous peoples reduce vulnerability in their communities.
\end{abstract}

Keywords: Natural hazards; community resilience; racial and ethnic justice.

\section{Conhecimento Indígena e Redução do Risco de Desastres}

RESUMO - Este artigo busca lançar luz sobre os desafios que os povos nativos enfrentam ao usarem o conhecimento indígena para reduzir o risco e mitigar os efeitos dos riscos naturais, incluindo incêndios florestais, e chama a atenção para as formas em que a prática tradicional, assim como a experiência contemporânea, pode ajudar os povos indígenas a reduzir a vulnerabilidade em suas comunidades.

Palavras-chave: Riscos naturais; comunidade resiliente; justiça racial e étnica.

\section{Conocimiento Indígena y Reducción del Riesgo de Desastres}

RESUMEN - Este artículo intenta arrojar luz sobre los desafíos al uso de los conocimientos indígenas por parte de los pueblos indígenas para reducir el riesgo y mitigar los efectos de los peligros naturales, incluidos los incendios forestales, y llama la atención sobre las formas en que la práctica tradicional, junto con la experiencia contemporánea, pueden ayudar a los pueblos indígenas a reducir la vulnerabilidad en sus comunidades.

Palabras clave: Amenazas naturales; resiliencia comunitaria; justicia racial y étnica.

\section{This time}

There is a groundswell of change, an awakening or perhaps a reawakening of longignored issues of race and ethnicity that passionate, often youthful, voices insist must be addressed. Called to account, now, are privileged communities that have persisted in marginalizing indigenous people and others whose values and beliefs, whose culture and "worldview" is different from their own. Over time and at an increasing rate, the imposition of outside development is adversely affecting the environment of indigenous people, restricting traditional risk reduction practices and, at times, making indigenous knowledges irrelevant.
Yet those traditional indigenous knowledges, values and cultures are, in themselves, important risk reduction tools and should be celebrated as such. The call for political and social change is echoing worldwide. Maybe this time change will be lasting.

What will this change look like and how deep will to go? And what should we hope will transpire between the $7^{\text {th }}$ and the $8^{\text {th }}$ International Wildland Fires Conferences?

From that introduction it may seem like a radical shift of topic to talk of risk reduction in indigenous communities. But the connection of these concerns to the vulnerability of indigenous 
peoples to natural hazards is a good example of how complicated the issues of ethnic and environmental justice are and how much work there is to be done on so many fronts.

Throughout the world, colonizers and their successors have reaped the fruits of their dominance - opportunity, security, freedom and prosperity. The term structural racism is often used to describe the historical and contemporary policies and practices that create and maintain racial and ethnic injustice. Privileged communities, through intentional oppression, ignorance or benign neglect have persisted in marginalizing indigenous people and others whose values and beliefs, whose culture and "worldview" is different from their own.

Foundations for effective disaster risk management in indigenous communities are rooted in these cultural belief systems, these worldviews. However, there are few indigenous communities within which natural hazard risk reduction practices based on these cultural belief systems can be practiced. Implementing significant risk reduction strategies require freedoms that are not available to many marginalized Indigenous communities.

This is true with respect to wildland fire management, in particular. In their publication Indigenous Fire Stewardship (2019), Frank K. Lake and Amy Cardinal Christianson, with the help of several references, characterize the differences in the ways in which cultural burning was practiced historically under indigenous fire sovereignty and governance compared to modern fire governance and management:

The colonial worldview was that fires were destructive to the timber supply and dangerous to communities (Pyne, 2007). The process of colonization, in most instances, has severely limited indigenous fire stewardship practices (Kimmerer \& Lake, 2001; Mistry et al., 2016; Lewis et al., 2018). Colonial fire management has limited and reduced the frequency, seasonality, extent, and magnitude of cultural burning through fire suppression policies and regulatory authorities (Murphy, 1985; Timbrook et al., 1993; Murphy et al., 2007; Christianson, 2015; Lewis et al., 2018). The legacy of colonization on indigenous fire knowledges from genocide, forced removal, relocation, and acculturation efforts to westernize indigenous peoples has substantially limited cultural burning (Eriksen \& Hankins, 2014).
More broadly, local capacity, practice, knowledge and tradition that have been developed through a close relation to their natural environment have helped communities cope with local hazards and thrive for millennia in highly at-risk areas. In many cases, however, these practices, otherwise highly sustainable, have been lost due to social, political or economic change, leading to increased vulnerability.

An explanation for the historical disregard of indigenous knowledges in established disaster risk reduction may include issues associated with power relations stemming from colonial times and the dominance of Western values and ideas. Given that knowledge is power, in this case the power over resources and how they are employed, indigenous knowledges have been largely ignored by those who protect their own interests and established political structures. In neocolonial times, it has not been uncommon for the language and religion of the colonizer to be forced on indigenous peoples (it's no accident that today many indigenous people, and in particular youth, do not speak their native language (Twitchell, 2018). Other insidious and long-term implications include the loss of stories and storytelling and similar traditions of an oral culture as well as an erosion of traditional decision-making customs that defined trusteeship of the land and environment and, by extension how communities lived in harmony with nature.

Another no less subtle explanation for the loss of indigeneity is the march-of-time. Mr. Girma $\mathrm{H} /$ Michael, a senior consultant in the field of indigenous knowledge documentation, has worked as director of National Disaster Management Policy and Programing for the then Disaster Prevention and Preparedness Commis-sion and now National Disaster Risk Management Commission in Ethiopia. According to him, a growing existential challenge to the continuing practice of traditional knowledge in Pastoralist communities is the "advent of modernity" and its influence on the attitudes of the young generation towards traditional systems. It is Mr. Michael's opinion that as drought and political decisions regarding land use reduce the ability to sustain traditional family practice, young people are moving away from the traditional systems of their parents. He explains that although many youth continue to live within the family unit many are increasingly exposed to non-pastoral employment opportunities, and moving out of their ancestral homes following these opportunities (Scott, 2019). 
This calling to attention the effects of modernity is also echoed by Garth Harmsworth (Maori), an environmental scientist at Landcare Research (Manaaki Whenua), Palmerston North, New Zealand. Mr. Harmsworth observes (Scott, 2019) that the wider use of formal education and the exposure to other (Western) models, standards and values has contributed to a breaking down of traditional communication networks. This has also resulted in the undermining of the importance of elders within the society, allowing their knowledge to die with them.

\section{Back to basics: indigenous knowledges and disaster risk reduction 101}

Several key terms are used to discuss disaster risk reduction, including hazard, risk and vulnerability, and more recently, resilience. Although the terms response, relief, and recovery are not commonly associated with disaster risk reduction, they do figure in discussions surrounding disaster resilience and are more typically associated with post-event activities.

Wildland fires, for example, are natural hazards (though they can be caused or exacerbated by decisions and actions made by humans). The risk to a community associated with wildland fires is potential loss of life, injury, or destroyed or damaged assets. And a community is vulnerable to these risks if it lacks public awareness and engagement in prevention strategies as well as access to systems and infrastructure to deal with the detection and the combatting of fire; for example, sensor networks, GIS and satellite tracking as well as adequate telecommunications, aircraft and terrestrial vehicles and even basic tools such as water, fire retardants, axes, hooks, cutters and poles.

The resilience of a community is characterized by its ability to function throughout an event, or at least the ability to restore critical systems soon afterwards, thereby preventing or significantly mitigating disruption to lives, livelihoods and economies (resilience usually is not the result of luck. Rather, it is attributed to the development and implementation of community-specific risk reduction strategies). In the absence of resilience, communities can face severe consequences.
Extreme economic, health and environmental costs associated with disaster events, include livestock loss, crop failure, hunger, disease, starvation and famine. Further, there is an equal, or even larger, existential, threat to indigenous cultures from wildland fires, climate change and other natural hazards: the loss of their way of living that has been passed down over millennia.

While these terms and definitions have currency within the professional disaster risk reduction community, they may not translate to indigenous understanding. Definitions, concepts and standards related to disaster risk reduction and response must reflect both indigenous and non-indigenous perspectives. And efforts must be taken to develop risk reduction strategies and messages appropriate not only to the linguistic but also the cultural practices of communities.

In the broader context of risk reduction in indigenous communities, it is also important to consider what might seem to be a paradox, that indigenous communities may simultaneously exhibit vulnerability and resilience. Uekusa and Matthewman (2017) suggest that resilience often comes from earned strength which, in time, may become traditional indigenous knowledge. That is, individuals and communities, through adversity, may become stronger than they originally were, simply as a means of surviving daily emergencies and struggles. This is a useful, if new, observation, as it gets away from the assumption that Indigenous Peoples are resilient through some sort of cultural magic (i.e. DNA and culture do not confer resilience).

\section{Respect for indigenous knowledges}

Returning to the theme of racial and ethnic justice and its effect on risk reduction in indigenous communities, the response to this new call to be "woke" should include efforts to ensure that indigenous Peoples have their own voice in creation of strategies to reduce risk and vulnerability and that that voice should be listened to. Traditional indigenous knowledges, values and culture are, in themselves, important risk reduction tools and should be celebrated as such. Many might be valuable if incorporated into national disaster plans. The practice of imposing centralized solutions to local problems (many of 
which already have successful local solutions) can lessen the community's capacity to reduce risk and save lives.

An example of this can be found in Ethiopia. Pastoralism has developed over centuries out of the need to constantly adapt to the extreme climatic uncertainty and marginal landscapes of the dry lands and has been practiced for centuries. Pastoralists have sophisticated traditional methods to optimize water and land, moving and selling animals to deal with the effects of drought. Yet, in recent years, the dry lands of the Horn of Africa, of which Ethiopia is a part, have become some of the most vulnerable areas in the world. This is due in part to decades of political and economic marginalization, which has led to an erosion of pastoral assets. The imposition of these forces, over and above the existing environmental challenges, disrupt migration routes and access to dry season grazing areas and severely hinder pastoralists' abilities to move animals to different pasture, a key mechanism for coping with drought.

Other examples come from New Zealand. Garth Harmsworth, introduced earlier, explains that the change from the indigenous practice of well-managed subsistence gardening to widespread commercial cash cropping and the raising of livestock which has, in many cases, led to heavy land erosion, which in turn, has resulted in widespread destruction from flooding. Land that has been cleared to make way for larger plantations removes stabilizing vegetation that was previously protected under traditional Maori environmental management schemes.

It follows, then, that attempts to introduce "Western Science" and other external approaches to address natural hazard risk reduction needs in indigenous communities should not be the primary emphasis. Before attempts are made to bring indigenous communities into the mainstream "Western" risk reduction and resilience movement, if, indeed that proves to be the best course of action, attempts should be made to better understand the culture of risk reduction and resilience that has been resident in indigenous communities throughout generations. Taking steps towards a better understanding of indigenous cultural belief systems (a.k.a., worldview, cosmovision, indigenous knowledge) and how they apply to disaster risk reduction and resilience should be a first step, not an adjunct exercise, in a collective effort to reduce risk in indigenous communities.

\section{Moving forward}

As we move forward we must agree to avoid furthering indoctrination of the false dichotomy of the "scientific" vs. "indigenous" knowledge. They go hand-in-hand; empirical evidence is a central part of the scientific method and empirical evidence is at the core of indigenous knowledge. Respect must be given to indigenous knowledges and opportunity must be available to indigenous peoples to fully represent their knowledge.

First Nations knowledge keeper Henry Michel, in his introduction to the proceedings of the "Linking Indigenous Peoples' Knowledge and Western Science in Natural Resource Management Conference" (Mitchel \& Gayton, 2001) explained it this way,

There are many misconceptions about $I P K$ both in the general public and within the Aboriginal community itself. If nonindigenous participants are exposed to $I P K$ as a system based on real concepts and practices, they can begin dismantling popular Western stereotypes of IPK as some elusive philosophy or superstition. Indigenous knowledge systems operate from the perspective of natural life systems. The natural laws of life - land, water, wind, the four cardinal directions, plants, animals, and humans - are the essential elements of those laws. The interrelationships that exist between these life elements are the basis of the natural laws. Indigenous knowledge systems and governance structures are modelled from these natural law principles. Western society has been so displaced from these natural world systems in which IPK is based that its value system has also become removed from nature. The incorporation of IPK systems with Western science will mean Western society must re-establish linkages based on natural systems thinking.

An example of the kind of linkage Henry Michel speaks of may be the Inuit Traditional Knowledge for Adapting to the Health Effects of Climate Change project (IK-ADAPT). The project was a multi-year community-based initiative, 
funded by the Institute for Circumpolar Health Research, that combined scientific research and Inuit traditional knowledges to develop an evidentiary base to inform policy and programming needed to assist Inuit communities in adapting to the health effects of climate change. Working in partnership with communities across Northern Canada, the program examined ways to preserve, promote, and disseminate traditional knowledges in order to prevent, prepare for, and manage the health impacts of climate change.

Heretofore, the terms "indigenous knowledge" and "traditional knowledge" have been used as placeholders - in meetings, conferences, needs assessments, policies, etc. - for a broader and deeper discussion that should and would happen at some time... but rarely seems to happen. It has been used to suggest that a deliberative body has given reasonable consideration to the necessity to respect indigenous peoples, their experience and their needs, without defining what that experience was, what those needs are or how, specifically, they would be met. And too frequently, when reports of meetings or findings of assessments were written, the words used were not the words of the indigenous delegates themselves; for, more often than not, there was neither a sufficient number of indigenous delegates assembled, nor was there enough time to discuss various indigenous perspectives (they are not homogenous), nor were sufficient interpretation and translation resources available, nor... ad infinitum, to accurately represent the many and varied needs of the communities about whom the meetings were convened and the assessments commissioned.

Will things change? Maybe this time. Because it's time.

\section{References}

Lake FK \& Christianson AC. 2019 Indigenous Fire Stewardship, In: Springer Nature Switzerland AG.

Pyne SJ. 2007. Awful splendour: a fire history of Canada. UBC Press, Vancouver. 584p.

Kimmerer RW \& Lake FK. The role of Indigenous burning in land management. In: Journal of Forest 99(11): 36-41, 2001.

Mistry J, Bilbao BA \& Berardi A. Community owned solutions for fire management in tropical ecosystems: case studies from Indigenous communities of South
America. In: Philosophical Transactions of the Royal Society B, 371(1696): 20150174, 2016.

Lewis M, Christianson A \& Spinks M. Return to flame: reasons for burning in Lytton First Nation, British Columbia. Journal of Foretry, 116(2): 143-150, 2018.

Murphy PJ. 1985. History of forest and prairie fire control policy in Alberta. Alberta Energy and Natural Resources. Edmonton. 408p.

Timbrook J, Johnson JR \& Earle DD. 1993. Vegetation burning by the Chumash, p 117-149. In: Blackburn TC \& Anderson $\mathrm{K}$ (orgs). Before the wilderness: environmental management by Native Californians. Ballena Press, Menlo Park. 476p.

Murphy A, Abrams J, Daniel T \& Yazzie V. Living amongst frequent fire forests: human history and cultural perspectives. Ecology and Society, 12(2): 17, 2017.

Christianson A. Social science research on Indigenous wildfire management in the 21st century and future research needs. In: International Journal of Wildland Fire 24(2): 190-200, 2015.

Lewis M, Christianson A \& Spinks M. Return to flame: reasons for burning in Lytton First Nation, British Columbia. Journal of Forestry, 116(2): 143-150, 2018.

Eriksen C \& Hankins DL. The retention, revival, and subjugation of Indigenous fire knowledge through agency fire fighting in Eastern Australia and California. Society \& Natural Resources, 27(12): 1288-1303, 2014.

Twitchell XL. 2018. For our little grandchildren: Language revitalization among the Tlingit. Thesis (doctorate degree). University of Hawai'i, Hilo, Hawai' (Unpliblished).

Scott JC. Exploration of Indigenous Practices and Knowledge Concerning Natural Hazards and Risk Reduction Case Study: The Afar Pastoralists of Ethiopia. Center for Public Service Communications (Unpublished), 2019.

Scott JC. Exploration of Indigenous Practices and Knowledge Concerning Natural Hazards and Risk Reduction Case Study: Maori of Aotearoa/New Zealand. Center for Public Service Communications (Unpublished), 2019.

Uekusa S \& Matthewman S. Vulnerable and resilient? Immigrants and refugees in the 2010-2011 Canterbury and Tohoku disasters. International Journal of Disaster Risk Reduction 22: 355-361, 2017.

Michel H. Gayton DV (orgs) 2001. Linking Indigenous Peoples' Knowledge and Western Science in Natural Resource Management, Conference Proceedings. Southern Interior Forest Extension and Research Partnership. 72p. 
ICHR (Institute for Circumpolar Health Research). Inuit Traditional Knowledge for Adapting to the Health Effects of Climate Change. <http://www.ichr.ca/research/ inuit-traditional-knowledge-for-adapting-to-the-healtheffects-of-climate-change-ik-adapt/>

Biodiversidade Brasileira - BioBrasil.

Edição Temática: 7th International Wildland Fire Conference

n. 2, 2021

http://www.icmbio.gov.br/revistaeletronica/index.php/BioBR

Biodiversidade Brasileira é uma publicação eletrônica científica do Instituto Chico Mendes de

Conservação da Biodiversidade (ICMBio) que tem como objetivo fomentar a discussão e a disseminação de experiências em conservação e manejo, com foco em unidades de conservação e espécies ameaçadas.

ISSN: 2236-2886 